Conclusions 1. Results of this analysis do not support the use of FVC as a surrogate end-point for mortality or hospitalisation in IPF, sarcoidosis or bronchiectasis trials. 2. Reporting of FVC in clinical trials is highly variable making synthesis of results for meta-analysis difficult. We suggest all trials make available baseline, final and change in FVC, both unadjusted and percent predicted, and as relative (\% change), at least in an online appendix.

\section{S15 FVC OR TLCO? IMPACT ON TREATMENT FOLLOWING NICE (NATIONAL INSTITUTE FOR HEALTH AND CARE EXCELLENCE) APPROVAL OF PIRFENIDONE}

G Saini, T McKeever, R Braybrooke, R Hubbard, G Jenkins; University of Nottingham, Nottingham, UK

\subsection{6/thoraxjnl-2013-204457.21}

Introduction Idiopathic Pulmonary Fibrosis (IPF) is a progressive, fatal lung disease with median survival of 3 years (1). NICE has recently approved Pirfenidone, which is the first licensed treatment for IPF. Pirfenidone is licensed for mild to moderate IPF, and the current NICE recommendation is that all patients with FVC (Forced Vital capacity) between $50-80 \%$ predicted should be considered for therapy. However, there is no agreed classification of disease severity in IPF. In clinical practice a combination of both FVC and $\mathrm{DL}_{\mathrm{CO}}$ (diffusion of lung carbon monoxide) is used to monitor disease progression. We explore the practical impact of using FVC on Pirfenidone prescribing.

Methods 218 incident cases of IPF have been enrolled in a prospective cohort study PROFILE in Central England from September 2009 to June 2013. All patients had a diagnosis of definite or probable IPF based on the ATS consensus 2000. The patients were stratified according to both FVC and DLco. Lung function defects were considered mild (FVC>80\%, $\mathrm{DL}_{\mathrm{CO}}>60 \%$ ), moderate (FVC 50-80\%, DL $\mathrm{CO} 40-60 \%$ ) and severe $\left(\mathrm{FVC}<50 \%, \mathrm{DL}_{\mathrm{CO}}<40 \%\right)$.

Results The median age was 72 years with majority cohort males (77\% males' vs $23 \%$ females). $181(84 \%)$ cases met diagnostic criteria for definite IPF. There was only a moderate correlation between FVC and $\mathrm{T}_{\mathrm{L}} \mathrm{CO}$ with correlation coefficient $=0.54$ and $\mathrm{p}<0.001$. A total of 79 patients $(44 \%)$ would be eligible for treatment based on FVC criteria. However, this includes 46 patients $(25 \%)$ who might be considered to have severe disease based on DLco criteria. (Table 1)

Conclusion Over half our patients eligible for Pirfenidone, based on current NICE criteria, will have severely reduced $\mathrm{DL}_{\mathrm{CO}}$. This highlights the need for an agreed classification of IPF disease severity. Follow up of PROFILE study patients may help guide a classification system.

\section{REFERENCES}

1. Navaratnam et al, Thorax 2011 Jun;66(6):462-7. doi: 10.1136/thoraxjnl-2013204457.22

Abstract S15 Table 1. PROFILE cohort September 2009 to June 2013 Nottingham \& Central England NHS Trust

\begin{tabular}{lllll}
\hline & \multicolumn{2}{l}{ FVC at diagnosis } & \\
\cline { 2 - 4 } $\mathrm{DL}_{\mathrm{co}}(\downarrow)$ & $\begin{array}{l}\text { Mild } \\
(>80 \%)\end{array}$ & $\begin{array}{l}\text { Moderate } \\
(\mathbf{5 0 - 8 0 \% )}\end{array}$ & $\begin{array}{l}\text { Severe } \\
(<50 \%)\end{array}$ & $\begin{array}{l}\text { Total } \\
(\mathbf{n})\end{array}$ \\
\hline Mild $(>60 \%)$ & 34 & 4 & 0 & 38 \\
Moderate $(40-60 \%)$ & 40 & 29 & 1 & 70 \\
Severe $(<40 \%)$ & 22 & 46 & 5 & 73 \\
Total $(\mathrm{n})$ & 96 & 79 & 6 & 181 \\
\hline
\end{tabular}

S16

OUTCOMES IN IDIOPATHIC PULMONARY FIBROSIS: A META-ANALYSIS FROM PLACEBO CONTROLLED TRIALS

${ }^{1} \mathrm{CP}$ Atkins, ${ }^{2}$ YK Loke, ${ }^{1} \mathrm{AM}$ Wilson; ${ }^{1}$ Norfolk and Norwich University Hospital, Norwich, Norfolk; ${ }^{2}$ Norwich Medical School, University of East Anglia, Norwich, Norfolk

\subsection{6/thoraxjnl-2013-204457.23}

Background Much of the data regarding the natural history of Idiopathic pulmonary fibrosis (IPF) pre-dates current clinical criteria. Despite high mortality debate has been sparked recently regarding the appropriateness of mortality as an endpoint for clinical trials. Additionally, respiratory infections are seen to have a role in the natural history of IPF. We aimed to evaluate the frequency of mortality and respiratory infections in the placebo arms of IPF trials.

Methods We identified randomised, placebo-controlled trials of IPF though a systematic review of MEDLINE, EMBASE, AMED and Cochrane central. Outcomes were mortality and lower respiratory tract infection (LRTI). We standardised event rates and compared differences using incidence rate ratios between subgroups of trials, according to disease severity inclusion or use of low-dose corticosteroids).

Results Thirteentrials were included, involving 1631 patients (2067.7 patient-years of follow-up). Standardised mortality was 91.9 deaths per 1,000 patient-years (range 18.8 to 224.5 per 1,000 years), though rates were higher in trials permitting lowdose immunosuppression and lower in trials excluding severe disease (table 1). Rates of respiratory tract infections were higher in trials including severe disease and in trials including patients receiving immunosuppression (table 1 )

Conclusion Mortality rate was heterogenous and dependent on entry criteria, with rates in studies excluding severe disease half that of unselected studies. Rates of infection in IPF are high, even without concurrent use of immunosuppression. Given low mortality rates, consideration should be given to alternative primary outcomes to mortality in future IPF trials of patients with mild-moderate disease.

\begin{tabular}{|c|c|c|c|c|}
\hline & \multicolumn{2}{|c|}{$\begin{array}{l}\text { Rate per } 1,000 \\
\text { patient-years follow-up }\end{array}$} & \multicolumn{2}{|c|}{$\begin{array}{l}\text { Incidence rate ratio } \\
\text { (95\% C.I.) }\end{array}$} \\
\hline & $\begin{array}{l}\text { Standardised } \\
\text { Mortality Rate }\end{array}$ & $\begin{array}{l}\text { Standardised } \\
\text { LRTI Rate }\end{array}$ & Mortality & LRTIS \\
\hline All trials & 91.9 & 172.5 & - & - \\
\hline $\begin{array}{l}\text { Permitting } \\
\text { low-dose (<20mg/day) } \\
\text { steroids }\end{array}$ & 95.8 & 227.1 & & \\
\hline No steroids & 72.9 & 63.4 & $\begin{array}{l}1.31 \\
(0.93-1.88)\end{array}$ & $\begin{array}{l}3.58 \\
(2.16-5.13)\end{array}$ \\
\hline $\begin{array}{l}\text { Severe disease } \\
(\text { FVC }<55 \%) \text { included }\end{array}$ & 188.6 & 257.8 & & \\
\hline $\begin{array}{l}\text { Severe disease } \\
\text { excluded }\end{array}$ & 78.6 & 153.9 & $\begin{array}{l}0.42 \\
(0.30-0.59)\end{array}$ & $\begin{array}{l}0.60 \\
(0.45-0.81)\end{array}$ \\
\hline
\end{tabular}

\section{S17 A PROTHROMBOTIC STATE IS ASSOCIATED WITH INCREASED MORTALITY IN IDIOPATHIC PULMONARY FIBROSIS}

${ }^{1} \mathrm{~V}$ Navaratnam, ${ }^{1} \mathrm{~A}$ Fogarty, ${ }^{1} \mathrm{~T}$ McKeever, ${ }^{2} \mathrm{~N}$ Thompson, ${ }^{2} \mathrm{RG}$ Jenkins, ${ }^{3} \mathrm{SR}$ Johnson, ${ }^{4} \mathrm{G}$ Dolan, ${ }^{5} \mathrm{M}$ Kumaran, ${ }^{5} \mathrm{~K}$ Pointon, ${ }^{1} \mathrm{RB}$ Hubbard; ${ }^{1}$ Division of Epidemiology and Public 
Spoken sessions

Abstract S17 Table 1. Cox regression modelling of clotting defects and survival in IPF

\begin{tabular}{|c|c|c|c|c|c|c|}
\hline Clotting defect & $\begin{array}{l}\text { Number of } \\
\text { deaths }\end{array}$ & Person-years & $\begin{array}{l}\text { Mortality rate per } 1000 \text { person } \\
\text { years }(95 \% \mathrm{Cl})\end{array}$ & $\begin{array}{l}\text { Hazard Ratio } \\
(95 \% \mathrm{Cl})^{*}\end{array}$ & $\begin{array}{l}\text { Hazard Ratio } \\
(95 \% \mathrm{Cl})^{\#}\end{array}$ & $p$ value \\
\hline No clotting defects & 8 & 86.7 & $92.3(46.2-184.6)$ & 1.00 & 1.00 & 0.0013 \\
\hline Prothrombotic state & 78 & 298.9 & $257.6(206.1-322.1)$ & $2.85(1.37-5.93)$ & $2.77(1.28-5.99)$ & 0.0039 \\
\hline
\end{tabular}

Health, University of Nottingham, Nottingham, United Kingdom; ${ }^{2}$ Nottingham Respiratory Research Unit, Nottingham, United Kingdom; ${ }^{3}$ Division of Therapeutics and Molecular Medicine, University of Nottingham, Nottingham, United Kingdom; ${ }^{4}$ Department of Haematology, Nottingham University Hospitals NHS Trust, Nottingham, United Kingdom; ${ }^{5}$ Department of Radiology, Nottingham University Hospitals NHS Trust, Nottingham, United Kingdom

\subsection{6/thoraxjnl-2013-204457.24}

Background Our previous case-control study demonstrated that a prothrombotic state was almost five times more common in people with idiopathic pulmonary fibrosis (IPF) than general population controls. We followed up the incident cases of IPF to determine if a prothrombotic state altered prognosis in terms of survival.

Methods People with IPF were recruited from five teaching and eight district general hospitals in England and Wales. All participants were asked for details of medical history, medication and smoking habit. Venous blood samples were taken to test for inherited and acquired clotting defects. We also collected high resolution computed tomography (HRCT) scans and pulmonary function tests done as part of routine care. All HRCT scans were reviewed by two thoracic radiologists to confirm the diagnosis of IPF. A prothrombotic state was defined as having at least one of the inherited or acquired clotting defects tested. Cox regression modelling was used to investigate the association between a prothrombotic state and survival amongst people with IPF, adjusting for age, sex, highly sensitive C Reactive Protein (hsCRP), smoking habit and baseline pulmonary function indices.

Results There were 211 incident cases of definite or probable IPF with a median follow up of 2 years (IQR: 1.2 to 2.5). During this time, 86 out of the 211 (40.8\%) cases died, which equates to an overall mortality rate of 220.5 per 1000 person years (95\% CI: 178.2 to 272.7 ). 78 out of the 86 deaths $(90.7 \%)$ were in individuals with a prothrombotic state (see Table 1). The proportion of the IPF cohort surviving at 2 years was $84.7 \%$ in patients without any clotting defects and $61.1 \%$ in patients with a prothrombotic state $(\mathrm{p}=0.0035)$.

Conclusions A prothrombotic state is associated with increased mortality amongst people with IPF. Further research into manipulation of the clotting cascade to improve the outlook of people with IPF is warranted.

\section{Asthma biology}

\section{S18 ACTIVATION OF NOCICEPTIN ORPHANIN FQ (N/OFQ) - N/OFQ PEPTIDE (NOP) RECEPTOR SYSTEM PLAYS A KEY IMMUNOMODULATORY ROLE IN ASTHMA}

\footnotetext{
${ }^{1} \mathrm{R}$ Singh, ${ }^{2} \mathrm{~N}$ Sullo, ${ }^{2} \mathrm{M}$ Matteis, ${ }^{2} \mathrm{G}$ Spaziano, ${ }^{1} \mathrm{~J}$ McDonald, ${ }^{1} \mathrm{R}$ Saunders, ${ }^{1} \mathrm{~L}$ Woodman, ${ }^{2} \mathrm{~K}$ Urbanek, ${ }^{2} \mathrm{~A}$ DeAngelis, ${ }^{2} \mathrm{R}$ DePalma, ${ }^{1} \mathrm{R}$ Berair, ${ }^{1} \mathrm{M}$ Pancholi, ${ }^{1} \mathrm{~V}$ Mistry, ${ }^{1} \mathrm{P}$ Bradding, ${ }^{2} \mathrm{~F}$ Rossi, ${ }^{3} \mathrm{R}$ Guerrini, ${ }^{3} \mathrm{G}$ Calo, ${ }^{2} \mathrm{~B}$ D'Agostino, ${ }^{1} \mathrm{C}$ E Brightling, ${ }^{1} \mathrm{D} \mathrm{G}$ Lambert; ${ }^{1}$ University Of Leichester, Leichester, UK; ${ }^{2}$ SecondUniversity of Naples, Naples, Italy; ${ }^{3}$ University of Ferrara, Ferrara, Italy
}

10.1136/thoraxjnl-2013-204457.25
Asthma is a complex heterogeneous disease characterised by variable airflow obstruction, bronchial hyper-responsiveness, airway inflammation and remodelling. The heptadecapeptide nociceptin/orphanin FQ (N/OFQ) is the endogenous ligand for the N/OFQ peptide (NOP) receptor, a non-opioid member of the opioid receptor family. The role of N/OFQ-NOP system in asthma is uncertain. We sought to evaluate N/OFQ-NOP expression in healthy and asthmatic human airway tissues and relate this to an established animal model of asthma.

NOP expression in human airway cells was investigated predominantly by qRT-PCR. The functional role of N/OFQ on human airway structural and immune cells was then interrogated using a range of functional assays including proliferation,migration,collagen gel contraction and wound healing. We further investigated the functional role of N/OFQ in vivo using ovalbumin-sensitised mice.

NOP expression was detected in human airway smooth muscle cells (HASM; mean?C? $=11 \pm 0.7, \mathrm{n}=13$ ), bronchial epithelial cells (HBEC;mean?C? $=10 \pm 0.49, \mathrm{n}=12$ ), lung mast cells (mean?C? $=7 \pm 0.64, \mathrm{n}=5$ ) and peripheral blood eosinophils (mean? $\mathrm{C} ?=10.4 \pm 1.2, \mathrm{n}=16$ ). N/OFQ inhibited chemoattractant-induced migration of mast cells and eosinophils (see Figure). N/OFQ stimulated significant HBEC wound closure with $49.62 \pm 3.58 \%(\mathrm{p}<0.001, \mathrm{n}=8)$ of the wound area

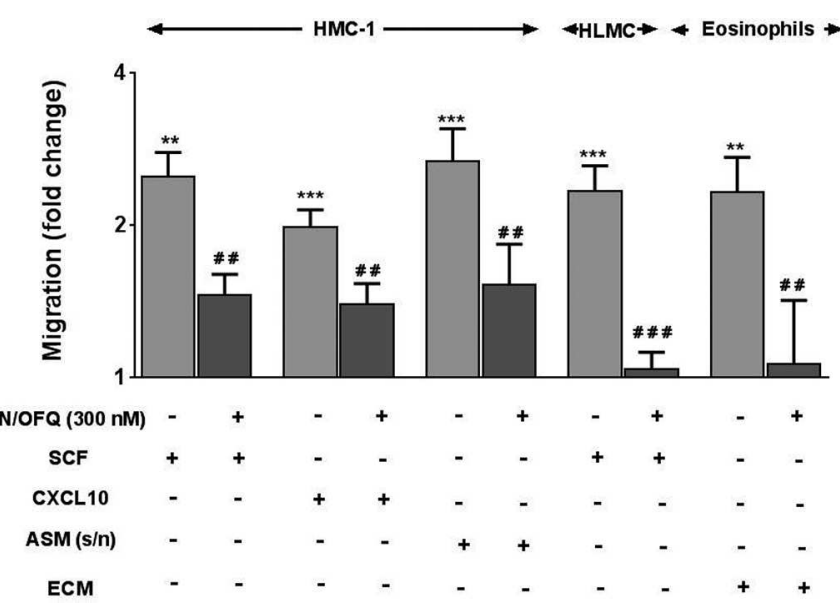

Abstract S18 Figure 1. N/OFQ inhibits chemoattractant-induced migration of lung mast cells and eosinophils. Migration of HMC-I cells (through an 8- $\mu \mathrm{m}$ pore-size transwell membrane) was enhanced following stimulation With SCF $(p<0.01, n=5)$, CXCL10 $(p<0.001, n=5)$ and TNF- $\alpha$ stimulated ASM s/n $(\mathrm{p}<0.001, \mathrm{n}=8)$ and this was significantly inhibited by N/OFQ $(\mathbf{p}<0.01)$. HLMC migration induced by SCF $(\mathbf{p}<0.001, \mathbf{n}=7)$ was significantly attenuated by N/OFQ $(p<0.001, n=7)$. Migration of peripheral blood eosinophils $(n=6)$ stimulated by epithelial conditioned media $(p<0.01)$ was significantly inhibited by N/OFQ $(p<0.01)$. Cell counts were performed by a blinded observer and data was represented as fold change over control in $\log (2)$ scale (mean \pm SEM). Statistical analysis was performed by one-Way ANOVA With Bonferroni's multiple comparison test. (*: $p$ value vs control; \#: $p$ value vs different relevant stimulation). 